\title{
1. Human rights and commercialization
}

This book explores the legal dynamics impeding the human right to health from becoming more widely enjoyed, while at the same time proposing an avenue to address that limitation. This first chapter advances the basic argument that contemporary human rights law cannot ensure a universal distribution of the right to health because it neglects to develop the duties that this right requires. Drawing from public health and social theory insights that accentuate the necessity to relate rights to institutions, this chapter invites human rights lawyers, especially those educated in the West, to put an end to the pernicious habit of caring for rights without caring equally for duties.

I argue that the principle of solidarity should inform the duties of the social right to health. Solidarity helps overcome the original indifference of official human rights law frameworks towards the commercialization of healthcare while in tandem opening the space necessary to move towards non-marketed conceptions of human rights based on public healthcare services. As such, this book is both a normative critique of the official understanding of the human right to health, but it can also be more widely understood as a critique about the limitations and biases of the current theory of human rights law, which result in the unfulfilled promise of social rights.

\section{THE DUTIES OF SOCIAL RIGHTS}

Contemporary societies are shaped by the notion of rights. ${ }^{1}$ Although the legal tradition of rights is far from exclusive in Western legal thinking, ${ }^{2}$ practically all contemporary justice theories have aligned to the discursive and institutional framework of rights. ${ }^{3}$

\footnotetext{
1 Unless stated otherwise, the expression 'rights' is intended to mean individual legal rights.

2 Christian moral reasoning, for instance, is critical of the self-assertiveness and individualism inherent in rights, an anthropocentrism that may end up obscuring the importance of the community and other aspects of the creation such as animals or the environment, as well as critical concepts such as duties, see Isabella Bunn, The Right to Development and International Economic Law. Legal and Moral Dimensions (Hart Publishing 2012) 83-84.

3 Except for the Communitarian and the Marxist tradition, most Western contemporary political philosophy does not conflict with rights. In distinguishing his influen-
} 
The legal nature of rights consists of something that must be either given or not taken away from the legal subject. ${ }^{4}$ In the context of the history of human rights, it is still controversial to argue that the operation of rights is only successful when a duty-bearer is identified. ${ }^{5}$ Yet, a dichotomy between rights and duties is odd given that the most widespread theoretical classification - Hohfeld's - admits that the fulfilment of rights depends on the accomplishment of legal duties. ${ }^{6}$

The point of departure of this work is that it is useless to speak of rights without clearly identifying duties, something that seems even truer in the context of social rights ${ }^{7}$ in the era of commercialization. Therefore, one of the

tial justice-as-fairness theory from utilitarianism, John Rawls established a framework compatible with the idea of rights, John Rawls, A Theory of Justice (originally published 1971, reprint, HUP) 31.

4 As stated by Costas Douzinas, legal subjectivity does not consist in a natural entity but in a legal construct. Costas Douzinas, The End of Human Rights: Critical Legal Thought at the Turn of the Century (Hart Publishing 2000) 233. The legal subject of human rights can include one or more individuals as in the case of group rights. In opposition to the traditional legal subjectivity of human rights constructed in the second half of the twentieth century (eg Thomas Buergenthal, 'To Respect and to Ensure: State Obligations and Permissible Derogations' in Louis Henkin (ed), The International Bill of Rights. The Covenant on Civil and Political Rights (Columbia University Press 1981) 72, 73), recent jurisprudential developments appear to be extending this legal subjectivity to non-persons such as corporations. In Citizens United v Federal Election Commission, the United States Supreme Court held that the government's restriction on corporations from making independent expenditures for political campaigns was contrary to the First Amendment, Appeal from the United States district court for the district of Columbia, 21 January, $\mathrm{N}^{\circ} 08-205,558$ U S 310.

5 This may be linked to the decisive influence of Rawlsian philosophy, which maintained that the idea of the right held precedence over the idea of the good. Rawls (n 3) 31; International Council on Human Rights Policy, Taking Duties Seriously: Individual Duties in International Human Rights Law. A Commentary (Versoix 1999) $1-2$.

6 In this sense, the emphasis on rights to the detriment of duties should be regarded as an oddity also from a Western legal perspective. See eg Wesley Hohfeld, Fundamental Legal Conceptions. As Applied in Judicial Reasoning (originally published 1919, Greenwood Press 1978) 38; Kelsen emphasized the importance of the duty bearer by stating that "the subject".. is the only obligated individual - the one who can violate or fulfil the obligation by his behaviour; the "entitled" individual - the one toward whom the behaviour is to take place - is only the object of the behaviour which, because corresponding to the obligated behaviour, is codetermined by the latter'. Hans Kelsen, Pure Theory of Law (first published 1967, University of California Press 1970) 127.

As Fernando Atria notes in his reading of TH Marshall, 'the incentive that operates in the free contract system of the open market is the incentive of personal gain. The incentive that corresponds to social rights is that of public duty'; see Fernando Atria, ‘Existen los Derechos Sociales?’ (2004) 4 Discusiones: Derechos Sociales 15, 18[9]; 
main goals of this work is to assess whether contemporary interpretational developments concerning the social right to health, which emphasize their judicial enforceability, help in identifying the duties without which this right cannot truly exist.

In unveiling the nature and complexities inherent to the duties of social rights, I will show that these cannot be explained exclusively through judicial dynamics. Social rights go further, and their object of study is more correctly placed at the intersection between three central themes: law and politics, social justice and human rights law, and the effort of combatting two distinct problems which should not be equated: poverty and inequality. ${ }^{8}$ The important question is in what way are social and economic inequalities the stuff of human rights law, or more succinctly, when does the law confront inequality?

Let me begin by providing context. It seems fair to suggest that democracy and human rights lose legitimacy where there is a background of excessive inequalities. Just look at the current global statistics: in 2018 it was calculated that 26 people possessed the same wealth as 3.8 billion people who constitute the poorest half of the planet. ${ }^{9}$ This reality appears to validate the Marxian critique that democracy under capitalism represents no more than a bourgeois form of liberty, unavailable to the proletarian classes. ${ }^{10}$ At the very least, a contradiction exists between societies shaped by the notion of rights against a background characterized by these disparities. ${ }^{11}$ Yet again, to what extent is greater inequality a signal of the failure of social rights?

Samuel Moyn, 'Rights vs. Duties: Reclaiming Civic Balance' Boston Review, 16 May $2016<$ https://bostonreview.net/books-ideas/samuel-moyn-rights-duties $>$ accessed 3 February 2021.

8 Samuel Moyn, Not Enough: Human Rights in an Unequal World (HUP Kindle Edition 2018) 3.

9 Oxfam International, 'Public Good or Private Wealth?' (January 2019) Oxfam Briefing Paper, 10[25] <https://oxfamilibrary.openrepository.com/bitstream/handle/ 10546/620599/bp-public-good-or-private-wealth-210119-summ-en.pdf?utm_source= indepth $>$ accessed 3 February 2021.

10 According to Brian Roper, the contradiction between democracy and capitalism stems from the 'undemocratic nature of capitalist relations of production. The generalized commodification of labour power disguises the authoritarian nature of social relations in the sphere of production (workplaces are generally organised hierarchically and undemocratically), and also the undemocratic nature of resource allocation by market mechanisms'. Brian Roper, The History of Democracy: A Marxist Interpretation (Pluto Press 2013) 238.

11 As has been recognized in UN declarations: Declaration on Social Progress and Development, UNGA Res 2542 (XXIV) 11 December 1969, preamble, art 2; Declaration on the Establishment of a New International Economic Order, UNGA Res 3201 (S-VI), 1 May 1974, 4(b); Rio Declaration on Environment and Development (1992) UN Doc A/CONF.151/26 (vol. I), 31 ILM 874, principle 5; OHCHR, 'Report 
The present study critically looks at these issues from the perspective of one single human right: the right to the highest attainable standard of health - hereafter 'the right to health' - under international human rights law. More specifically, this work refers only to access to health and within that, access to healthcare.

Embarking on this project takes one quickly towards the work of $\mathrm{TH}$ Marshall and his view that social rights contribute to diminishing the gap of inequality of condition. ${ }^{12}$ Yet, as he also stated, the main contribution of social rights is not to ensure an equal material reality, but to guarantee an equality of status. ${ }^{13}$ I understand this as the equal possibility for people to freely realize their personality. ${ }^{14}$ This view is consistent with the formulation of Article 22 of the Universal Declaration of Human Rights in the sense that the object of social rights is to guarantee 'the dignity and free development of the personality'. Yet, the idea that social rights pursue equality of status should not be used to disregard the importance of equality of outcome. Paraphrasing Anne Phillips, equality of outcome remains an unavoidable mechanism for measuring how authentic equality of opportunity was. ${ }^{15}$ My view is that this logic should be extended to the field of social rights.

Looking at the right to health from the perspective of international human rights law, I take the view that the lex lata element of this right is fundamentally based on Article 12 of the International Covenant on Economic, Social and Cultural Rights besides the important provision of its Article 2(1). ${ }^{16}$ In the

of the Independent Expert on Human Rights and International Solidarity, Virgina Dandan', UN Doc A/HRC/26/34, 1 April 2014, Annex, para 4(2)(a).

12 TH Marshall, Citizenship and Social Class and Other Essays (CUP 1950) 56.

13 ibid.

14 Johannes Morsink, The Universal Declaration of Human Rights: Origins, Drafting, and Intent (University of Pennsylvania Press 1999) 88; Ricardo García and Víctor de-Currea-Lugo emphasize its connection with liberty. Víctor de-Currea-Lugo, Cuadernos Deusto de Derechos Humanos. La Salud Como Derecho Humano: 15 Requisitos y una Mirada a las Reformas (Universidad de Deusto 2005) 23.

15 Addressing the problem of discrimination against women, Phillips puts the argument in this way: 'The crucial move is the claim that equality of opportunity is a chimera if it has not generated equality of outcome in these fields. If the result of all our disparate choices and opportunities is that men nonetheless congregate in the higher echelons of the economy, predominate in positions of political influence, sweep up all the literary prizes, and never collect the children from school, the presumption must be that the opportunities were not so equal. We can judge, that is, the extent of the equality by checking on the results, and should be reluctant to credit an initial equality of opportunity if the outcomes prove so dissimilar'. Anne Phillips, 'Defending Equality of Outcome' (2004) 12 The Journal of Political Philosophy 1, 6.

16 'Each State Party to the present Covenant undertakes to take steps, individually and through international assistance and co-operation, especially economic and techni- 
borderline between what the right to health is and what the right to health could and should be, lie a series of interpretations. ${ }^{17}$ I call the one on which I critically focus the predominant interpretation of the right to health. This interpretation transpires fundamentally from the contributions of two UN bodies: the Committee on Economic, Social and Cultural Rights - consisting specifically of this Committee's General Comments and Concluding Observations - and the reports of the Special Rapporteur for the Right to the Highest Attainable Standard of Health.

\section{OFFICIAL NARRATIVES OF THE RIGHT TO HEALTH}

Stemming from these interpretative instruments, three critical elements shape the predominant interpretation of the right to health.

First, from a procedural perspective, the right to health can be closely associated with access to justice. ${ }^{18}$ This book will be consequently occupied with the question of whether the great emphasis on the judicial enforceability of the right to health has helped in identifying the duties behind this human right. For a long time social rights have been perceived as the poorer relatives in the family of human rights - a secondary and less important category of rights. As I will show in more detail in chapter two, for the predominant interpretation

cal, to the maximum of its available resources, with a view to achieving progressively the full realization of the rights recognized in the present Covenant by all appropriate means, including particularly the adoption of legislative measures', International Covenant on Economic, Social and Cultural Rights (adopted on 16 December 1966) 993 UNTS 3, art 2(1).

17 The Limburg Principles corroborate that the principles themselves and the Concluding Observations of the United Nations Committee on Economic, Social and Cultural Rights are a set of 'recommendations' that 'should be taken into account', see UNCHR, 'Note Verbale Dated 5 December 1986 from the Permanent Mission of the Netherlands to the United Nations Office at Geneva Addressed to the Centre for Human Rights (“Limburg Principles”)' (8 January 1987) E/CN.4/1987/17, paras 5, 83; OHCHR, 'Economic, Social and Cultural Rights: Handbook for National Human Rights Institutions' (Professional Training Series 12, United Nations, 2005) 6; Eibe Riedel, 'The Human Right to Health: Conceptual Foundations' in Mary Robinson and Andrew Clapham (eds), Realising The Human Right to Health (3 Rüffer and Rub 2009); Brigit Toebes, 'Human Rights and Health Sector Corruption' in John Harrington and Maria Stuttaford (eds), Global Health and Human Rights: Legal and Philosophical Perspectives (Routledge 2010).

18 Limburg Principles (n 17) para 19; UNCESCR, 'General Comment 3: The Nature of States Parties' Obligations (Art 2, Para. 1, of the Covenant)', UN Doc E/1991/23, 14 December 1990, para 5; UNCESCR, 'General Comment 14 The Right to the Highest Attainable Standard of Health', UN Doc E/C.12/2004/4, 11 May 2000, para 60 . 
this limitation stems from the unwillingness to judicially adjudicate these rights. Consequently, a great deal of energy has been spent in matching the standards that have been applied in the context of civil and political rights.

This book argues that such a reaction misses the point. To be sure, there is no question that social rights have been the target of an ideological prejudice that has damaged the legitimacy of the human rights project. And while it is similarly true that certain elements of social rights can be the object of judicial adjudication, none of that leads to the conclusion that it is judicial adjudication which most definitively distinguishes social rights from other human rights. Contrarily, this book argues that the critical task ahead lies in identifying the social nature of social rights. In the case of the right to health, this task consists in the identification, characterization and upholding of this right's correlative duty, that is to say, the access to the universal public services with the ability to make the right to health probable.

Secondly, from a more substantive or content-based perspective, the predominant interpretation of the right to health leads towards an individual legal right to a minimum healthcare provision. ${ }^{19}$ This entitlement refers either to a specific healthcare treatment or a minimum healthcare provision over which the right holder would possess a sort of property right. ${ }^{20}$ I shall argue how this view is largely unable to identify the duties necessary for everyone to access equal healthcare. Moreover, I will show how, despite its targeted focus on the vulnerable, the legal rights approach has difficulties in focusing on the poor. This stems from the partial recognition of rights in the area of social rights, but

19 Limburg Principles (n 17) paras 25, 28; UNCESCR, Comment 3 (n 18) para 10; The Maastricht Guidelines on Violations of Economic, Social and Cultural Rights, 26 January 1997 <www.refworld.org/docid/48abd5730.html> accessed 3 February 2021 (Maastricht Guidelines) paras 9, 10, 14(g); UNCESCR, 'General Comment 2: International Technical Assistance Measures (Art 22 of the Covenant)', UN Doc E/1990/23, 2 February 1990, para 9; UNCESCR, 'General Comment 8: The Relationship between Economic Sanctions and Respect for Economic, Social and Cultural Rights', UN Doc E/C.12/1997/8, 12 December 1997, para 7; UNCESCR, Comment 14 (n 18) para 47; David Landau, 'The Reality of Social Rights Enforcement' (2012) 53(1) Harvard International Law Journal 402, 408.

20 One can observe a parallel with elements that derive from social rights such as the right to social security but due to rationae materiae limitations, they have been addressed through individual rights. Janneke Gerards has observed this development as elaborated by the European Court of Human Rights in the field of social benefits, where they would have been understood as 'possessions'. Gerards notes that the property construct (finally consolidated in the Stec case), together with the reasoning by analogy and case-based argumentation mechanisms of the Court, stimulate individuals 'acting out of self-interest' to bring their different interests to the Court. Janneke Gerards, 'The Prism of Fundamental Rights' (2012) 8(2) European Constitutional Review 173, 182. 
also from the acquiescence of the commercial logic around which healthcare services have been organized under the influx of neoliberalism.

Thirdly, and immediately connected with this minimalistic take on equity, the development of the predominant interpretation of the right to health develops what could be described as a peaceful coexistence between human rights and healthcare commercialization. Coming to this conjuncture, Mackintosh and Koivusalo have defined healthcare commercialization as a phenomenon that entails:

[T] he provision of health care services through market relationships to those able to pay; investment in, and production of, those services, and of inputs to them, for cash income or profit, including private contracting and supply to publicly financed health care; and health care finance derived from individual payment and private insurance. ${ }^{21}$

Healthcare commercialization has gradually made its way since the 1980s through the introduction of neoliberal style market reforms. Amongst the most impactful are those that took place in the US in the 1990s under the Clinton administration, and which were further developed under Obamacare. Similar policies have been replicated in very different countries like Colombia. Within this realm, for-profit organizations of providers and health financiers are organized through large, privately controlled organizations which are in turn controlled or strongly influenced by private insurance corporations. Health plans are sold to the public under restricted competition, while large numbers of physicians and hospitals become absorbed by these corporations. Workers and employers pay monthly contributions and different levels of out-of-pocket payments at the time of receiving healthcare services. The government similarly plays a significant role by heavily subsidizing the healthcare industry. ${ }^{22}$ According to Mackintosh and Koivusalo, the positive results of healthcare commercialization have been limited. Countries with lower commercialization of health expenditure have shown better health outcomes and, conversely,

21 Maureeen Mackintosh and Meri Koivusalo, 'Health Systems and Commercialization' in Maureeen Mackintosh and Meri Koivusalo, Commercialization of Health Care: Global and Local Dynamics and Policy Responses (Palgrave Macmillan 2005) 4.

22 Howard Waitzkin and Ida Hellander, 'Obamacare: The Neoliberal Model Comes Home to Roost in the United States - If We Let It' in Howard Waitzkin, Health Care Under The Knife: Moving Beyond Capitalism For Our Health (Monthly Review Press 2018) 104-111. See also, John Lister, Health Policy Reform: Global Health Versus Private Profit (Libri Publishing 2013) ch 7. 
countries that spend more of their GDP on health through public expenditure or social insurance have had significantly better health outcomes. ${ }^{23}$

The intermingling between human rights and healthcare commercialization derives, on the one hand, from the idea that accountability is ensured through a justiciability that operates irrespective from the private or public nature of the healthcare services themselves. ${ }^{24}$ The other point of contact emerges from the idea that everyone could - at least in theory - remain protected under commercial schemes if those who are able to pay for healthcare services do so themselves while those who cannot do so become eligible for a minimum human rights protection. ${ }^{25}$ This is consistent with commercialized healthcare policies, ${ }^{26}$ but also with ultra-libertarian views which on the one hand present themselves as opposed to destitution ${ }^{27}$ but which, on the other hand, do not accept collective efforts to protect principles like social justice, solidarity or, more generally, the struggle against inequality. ${ }^{28}$

The significant recourse to commercial arrangements in the delivery of healthcare services means that commercialization dynamics play a role in determining when human rights engagements will be considered pertinent. While it could seem reasonable to let those with resources pay for their own healthcare in a context of scarce resources, this perspective is confronted with a number of challenges, which this book will look at in further detail namely: (a) do commercial arrangements administer these scarce resources as efficiently as possible? (b) do commercial arrangements improve the position of the poor? (c) do the parallel systems (commercial vis-à-vis human rights minimums) replicate class inequalities harmful to human rights law? (d) do commercial approaches promote or antagonize human rights law more generally? The first overall question this book is dedicated to explore is whether the universalistic premises on which human rights law are built can be made compatible with commercialized approaches to healthcare. As a result, this book will discuss and further problematize whether the peaceful coexistence that has so far characterized the relationship between human rights law and

\footnotetext{
23 Mackintosh (n 21) 13-18.

24 UNCESCR, Comment 14 (n 18) paras 12(b), 35, 36.

25 General Comment 14 speaks of 'those who do not have sufficient means', UNCESCR, Comment 14 (n 18) para 19.

26 Waitzkin (n 22) 107-109.

27 Milton Friedman, Capitalism and Freedom (first published 1962, University of Chicago Press 2002) 191.

28 As it was the case of Hayek, for whom social justice was either 'pseudo-ethics' (FA Hayek, Law, Legislation and Liberty: A New Statement of the Liberal Principles of Justice and Political Economy (first published in 1982, Routledge 2013) 468), or 'some non-existing principle'. FA Hayek, The Constitution of Liberty (first published 1960, Routledge 1976) 302.
} 
healthcare commercialization, should be considered a desirable outcome in the context of the right to health.

\section{SOLIDARITY AND SOCIAL RIGHTS}

After this critical assessment, the book will shift toward a more forthcoming perspective, digging deeper to reveal another interpretation. I will thus defend what I consider to be a theoretically coherent standpoint permeating social rights in general, and the right to health in particular: the principle of solidarity.

Solidarity's added value lies in the idea that liberty in social rights is delimited by equality. ${ }^{29}$ No other principle involves this idea with the same normative specificity and distinctiveness. What solidarity does when defining the scope of social rights is to oppose an unequal liberty. ${ }^{30}$ This is reflected in the maxim popularized by Marx: from each according to his ability, to each according to his needs. ${ }^{31} \mathrm{My}$ goal is to explore whether solidarity can teach us something about the limitations, challenges and contradictions involved in an individualized understanding of the right to health while at the same time exploring what it means to link solidarity to the duties and institutions that make the right to health possible. In this way, the second overall question guiding this book is whether the principle of solidarity can provide an alternative interpretation for the right to health and, if so, how does solidarity give weight to the right to health?

Considering that armed conflict, air pollution, access to water and sewage, environmental protection or, more generally, action on the social determinants of health have a greater impact on human health and economic inequalities, ${ }^{32}$ focusing on healthcare may seem an arbitrary choice. I hope to be able to show, however, that the reasons for limiting this study to access to healthcare

29 This owes to the philosophy of New Liberalism, according to which liberty could be 'defined as something that people have or lack in common, and when the conflict of interest between capital and labour was recognized'. Svante Nycander, The History of Western Liberalism (Uppsala Universiteit 2016).

30 This is in line with Gerald Cohen's observation that in a market society 'money and its lack, imply relations of freedom and unfreedom' and that the protest against poverty is a plea 'against the extreme unfreedom of the poor in a capitalist society, and in favour of a much more equal distribution of freedom'. Michael Otsuka (ed), On the Currency of Egalitarian Justice, and Other Essays on Political Philosophy (Princeton University Press 2011) 184-86.

31 Karl Marx, Critique of the Gotha Programme (first published 1875, The Electric Book Company 2001) 20.

32 Octavio Ferraz and Fabiola Vieira, 'Direito à Saúde, Recursos Escassos e Equidade: Os Riscos da Interpretação Judicial Dominante’ (2009) 52(1) DADOS Revista de Ciências Sociais Rio de Janeiro 223, 225. 
contribute to explaining why the right to health is in fact a human right and not a mere rhetorical device destined to invigorate social policy. In line with the Alma-Ata Declaration, ${ }^{33}$ the most efficient use of scarce resources is an issue of pivotal importance. Yet, if this were so, would a utilitarian approach - understood as the greatest impact for the greatest number - not then be the approach that would fit this study better? The most immediate reason why this is not the case lies in positive law: Article 12(2)(d) of the International Covenant on Economic, Social and Cultural Rights makes clear that the right to health is not just about the most cost-effective policy, but involves the integration of several actions, one of which is indeed healthcare. ${ }^{34}$

However, in my view, the most important reason why healthcare must be incorporated in any definition of the right to health is ethical in nature. ${ }^{35}$ When Dr Martin Luther King Jr stated that 'out of all disparities health inequities are the most shocking and inhumane', ${ }^{36}$ he was not only protesting against the narrowness of a theory of human rights that failed to include health, but was also shedding light on the social nature of this social right. If, by definition, indignity in health is comparative, the focus should not be placed on the individual's interest to obtain healthcare, but on healthcare as an issue that is too vital to be handled privately. It is therefore wrong to connect the right to health to the right of a person or a group of persons. Speaking about access to health also entails speaking about the social dimension of social rights.

Such a focus suggests that rather than the extension of an individual legal right, it is solidarity which gives this social right its distinctiveness. The study will show that when informed by solidarity, the right to health's goal is not simply to extend justiciability to social rights. Without prejudice to the fact that courts may be important in securing non-discrimination, this element, or individual justiciability of the right to health, is not what defines the protection of social rights. As this study shows, the overemphasis on access to court has distracted attention from what is really at stake in the right to health. As I argue in the second half of chapter four, the right to health calls for an interpretation in line with what I regard as the inherent elements of social rights: their dem-

33 WHO, 'Primary Health Care: Report of the International Conference on Primary Health Care, Alma-Ata, USSR' (6-12 September 1978) para VII (5).

34 Gorik Ooms and Rachel Hammonds, 'Taking Up Daniels' Challenge: The Case for Global Health Justice' (2010) 12(1) Health and Human Rights 29, 35.

35 Paul Hunt, a former Special Rapporteur for the Right to Health, defined it as a core social institution, UNCHR, 'Report of the Special Rapporteur on the Right of Everyone to the Enjoyment of the Highest Attainable Standard of Physical and Mental Health, Paul Hunt', UN Doc E/CN.4/2006/48, 3 March 2006, para 20.

36 Dr Martin Luther King Jr, 25 March 1966, 2nd National Convention of the Medical Committee for Human Rights. 
ocratic pedigree, the principles of distributive justice that these rights uphold, the trade-offs that describe the background to these rights and the collective nature of the remedies that best fit the right to health's social nature.

The 2008 financial crisis represents the beginning of the end of the triumphalist neoliberal, cosmopolitan and new constitutionalist expectations after the fall of the Berlin Wall. ${ }^{37} \mathrm{I}$ am sceptical of understandings of social rights that circumvent the crucial role of the State; not because the State unequivocally leads to emancipation, but, rather, on the assumption that if the State is not put at the service of the emancipatory ends, the human rights project will remain flawed. For this reason, I take the view that the duties arising from the right to health refer to an obligation that must be fulfilled primordially by the State and of which all human beings are prima facie recipients. ${ }^{38}$ Citizens no doubt belong to these recipients. ${ }^{39}$ Yet, I claim that all individuals subject to the State's jurisdiction are beneficiaries in the same terms as citizens. ${ }^{40}$ Moreover, in line with Article 28 of the Universal Declaration, the State obligation should be understood to reach every human being. Practical reasons and respect for the right to self-determination put the State in a position to comply with this obligation indirectly, via international cooperation.

It is important to note that my goal will not be to argue that the actual references to solidarity that exist in the different international materials generate new legal obligations. In establishing solidarity, although a formally foundational principle in human rights law that has remained largely unexplored, my goal is to inquire whether there are both theoretical and normative grounds for reinterpreting the legal horizons of the right to health. This task is carried out with the view that only a new vision on the duties of the right to health can help human rights re-establish their social justice roots. Currently, the right to health can do little to drive the question of access away from individual ability to pay. At the dawning of this twenty-first century, the interest-oriented nature of businesses run by the healthcare industry reveal a healthcare sector which is another expression of the era of commercialization. ${ }^{41}$ The challenge

37 An example can be found in Ferrajoli. Luigi Ferrajoli, Democracia y Garantismo (2nd edn, Trotta 2010) 38; a relatively early reaction against the economic triumphalism of the 1990s can be found in Joseph Stiglitz, Freefall: Free Markets and the Sinking of the Global Economy (Penguin Books 2010) 343.

38 David Dyzenhaus, Hard Cases in Wicked Legal Systems. Pathologies of Legality (OUP 2010) 288; Ricardo García Manrique, La Libertad de Todos: Una Defensa de los Derechos Sociales (El Viejo Topo 2013) 34-36; Steven Ratner, The Thin Justice of International Law: A Moral Reckoning of the Law of Nations (OUP 2015) 270.

39 Ratner, ibid 269-70.

40 ibid 269.

41 David Harvey, The Enigma of Capital and the Crises of Capitalism (Profile Books 2011) 220; Lister (n 22) 211; Joseph Stiglitz, The Price of Inequality (Penguin Books 2013) xxxi-xxxii, 121. 
in relation to the right to health entails a shift from this commercialization, that is, transforming the financing and provision of healthcare into a public service conditional only on citizenship and medical need.

I would like to close the point of solidarity with a final methodological note. Taking the perspective of solidarity in the context of this study is not grounded in a claim of impartiality. Solidarity does not fit the idea of legal, let alone scientific, neutrality. But the same can be said of any other legal notion that appears neutral today. Take the notion of equality: At the beginning of the European eighteenth century, when most people lived under the rule of absolute monarchs claiming to exercise their power by direct authorization from God, equality was certainly contested. And the same thing can be said of democracy and the human right to vote in the context of the European nineteenth and twentieth centuries and pretty much about every other legal notion. None of these perspectives are neutral, and they obtain their persuasiveness and legitimacy from historical events and historical contexts. By the same token, today's exceptions to the rule - monarchies in the twenty-first century, for example - are the clearest expression not only that principles are not neutral, but also that the most conspicuous advocates of the rule of law, democracy and human rights, by focusing on the challenges to democracy 'far away' are not neutral either. This corroboration, rather than leading to sceptical cynicism, should reinvigorate and help legitimize the efforts of legal scholars that understand human rights research as an emancipatory project at the service of the oppressed majorities of our world. The law does not work with aseptic materials. By putting forward the principle of solidarity, I am not attempting to convince the reader about the impartiality of this notion. My effort consists of providing arguments that will hopefully be persuasive about the ability of the legal construct of solidarity to provide a more consistent explanation of social rights and the right to health.

\section{STRUCTURE}

The book shall proceed as follows. Chapter two begins by looking at the predominant interpretation of the right to health. Generally a more descriptive kind of analysis, this starting point is essential as it allows me to contrast the present state of affairs of social rights with the principle of solidarity that will be presented further on. This transition to solidarity takes place by the end of the chapter, where a set of problems, hard to solve within the predominant paradigm, are formulated. One of the main problems is the inability of the predominant interpretation to clearly identify duties and institutions that are able to realize the promises of this human right.

Chapter three looks more closely at the principle of solidarity. The chapter traces some of solidarity's historical developments, and assesses those with 
value for international human rights law, specifically those linked to the right to health.

The study's main proposal is developed in full in chapter four. Delving into a more normative analysis, the chapter takes into consideration the insights of chapters two and three to formulate a critique against the predominant interpretation of the right to health. More specifically, I look at the aptitude of the legal techniques this interpretation deploys to realize the goals of this human right. I maintain that basic frameworks within human rights law, such as the normative framework of the right to health, as advanced by General Comments 3 and 14 , lead to an account that makes it hard to address the fundamental concerns of social rights. By the same token, the chapter shows how important notions within this trend, such as non-discrimination or affordability, do not lead to the consolidation, promotion or enforcement of the institutions needed to guarantee the main promise of this right - namely, equal access to healthcare for all. I argue that this is a major problem when it comes to enfranchising the entire community, equally. The chapter starts by critically addressing the expert literature and elements put forward in chapter two, and it concludes by examining the implications of a solidarity-based interpretation of this human right.

Chapters five and six are devoted to the jurisprudential and institutional implications derived from the discussion in chapter four. Chapter five assesses a selection of salient judicial decisions that have attracted international attention. The chapter develops a critical account of the ways in which the right to health has been enforced under the purview of the predominant interpretation of the right to health. Furthermore, the chapter seeks to answer what it means to adjudicate the right to health from the perspective of solidarity, and how this perspective helps the right to health become part of the distinctive category of social rights.

Chapter six argues that the legal rules concerning the provision and financing of health systems are the main challenges for the right to health to address. After looking at three different health-financing systems, the predominant interpretation of the right to health appears to fit much more easily with the application of medicalized focuses that could be detrimental to the financial sustainability of healthcare systems. On the contrary, the solidarity perspective of the right to health, developed in chapter four, fits more naturally with the free-of-charge focus that allows the right to health to be safeguarded universally and equally. 